\title{
Territorialização e trabalho: atuação dos aldeados de Ferradas no processo de ocupação e exploração territorial, no Sul da Bahia (século XIX)
}

\section{Ayalla Oliveira Silva*}

Resumo: Em início do século XIX, contexto em que se observa o crescente interesse pela expansão das áreas interioranas do Brasil colonial e posteriormente imperial, a política indigenista foi aplicada, no Sul da Bahia, com vistas a atender as demandas governamentais acerca do trabalho indígena e de suas terras. Nesse escopo, o aldeamento São Pedro de Alcântara, instalado em Ferradas em 1814, configurou-se como importante celeiro de mão de obra indígena para os trabalhos de abertura e conservação da estrada Ilhéus-Vitória. Os aldeados atuavam ainda nas fazendas do entorno do aldeamento, com especial atenção para o seu trabalho na incipiente lavoura do cacau. A partir do tratamento de diversas fontes, especialmente, as correspondências trocadas entre autoridades locais e provinciais, o objetivo deste artigo é perceber como se dava a atuação dos homens e mulheres territorializados nas demandas acerca da organização do trabalho, na região Sul da Bahia, durante o Oitocentos.

Palavras-chave: Sul da Bahia; territorialização; trabalho indígena.

Abstract: In the beginning of the $19^{\text {th }}$ century, in which it could be observed a growing interest for the country side of, first colonial and then imperial, Brazil it was applied the Indian policy in Southern Bahia. This policy was created in order to meet the governmental demands concerning the Indigenous labor and their land. Due to that, the São Pedro de Alcântara village, built in Ferradas in 1814, turned out to be an important gathering of indigenous labor used for the construction and maintenance of the road Ilhéus-Conquista. Besides that, people from the village would also work on the farms around the village, giving special attention to the incipient cacao farming. From a careful research of various sources, especially from mailing exchanges between provincial and local authorities, the goal here is to realize how the roles of territorialized men and women would be, concerning work organization, in Southern Bahia during the 1800 s.

Keywords: Southern Bahia; territorialization; indigenous labor.

* Mestre em História pela Universidade Federal Rural do Rio de Janeiro. Bolsista CAPES. E-mail: ayallasilva@ yahoo.com.br. 


\section{Introdução}

As populações indígenas em "situação de aldeamento" no Sul da Bahia, durante o século XIX, ainda têm sido objeto de poucos estudos da historiografia regional, no sentido de pensar as experiências históricas dos índios aldeados na dinâmica de formação e consolidação econômica e social da referida região.

A política indigenista de fins do Setecentos, bem como a do Oitocentos foram marcadas por dois objetivos bastante claros e correlacionados: ocupação territorial e mão de obra indígena. O trabalho dos homens e mulheres aldeados em Ferradas foi amplamente utilizado, durante quase todo o século XIX, nos serviços públicos e particulares voltados ao estabelecimento de colonos na região, à abertura e conservação da estrada que ligava as vilas Ilhéus e Vitória (hoje Vitória da Conquista), cujo funcionamento incidia diretamente nos contornos econômicos da região.

O Sul da Bahia configurou-se no decorrer do Oitocentos em "região cacaueira". Nesse processo, o trabalho dos homens e mulheres dos aldeamentos instalados na comarca de Ilhéus à época foi de extrema importância para a nova conformação social, política e econômica regional. No entanto, a narrativa memorialista sobre a região desconhece ou, pior ainda, propositalmente esconde a presença dos índios na formação da economia e sociedade regional, alegando que a formação da atual Itabuna se deve ao trabalho pioneiro dos imigrantes sergipanos, processo no qual os índios, quando são mencionados, o são como estorvo ao progresso regional. O objetivo empreendido neste texto, portanto é demonstrar a atuação do trabalho dos aldeados de Ferradas nos ramos dos serviços públicos e particulares, com especial atenção para a utilização da mão de obra indígena nos trabalhos da estrada Ilhéus-Vitória, bem como na formação da lavoura do cacau, no Sul da Bahia oitocentista.

\section{Política indigenista colonial e imperial: algumas considerações sobre o caráter da exploração da mão de obra dos índios aldeados}

A política indigenista do início do século XIX é marcada, segundo Carneiro da Cunha, por um hiato legislativo, tendo em vista a extinção do Diretório pombalino, em 1798, e vigência de outro conjunto de normas legislativas para os índios do Império, a partir de $1845 .{ }^{1}$

Ressalta-se, contudo que a ideia de um hiato legal, observado por Manuela Carneiro da Cunha, na governança dos índios após o Diretório pombalino, tem sido repensada mais recentemente pela reflexão de historiadores, como Patrícia Sampaio.

Para Sampaio, a existência de uma lacuna legal, como assegura Cunha acerca do contexto indigenista posterior à extinção do Diretório pombalino, poderia ser considerada no sentido de que a Carta régia de 1798 não tenha se tornado uma nova política indigenista geral. ${ }^{2}$ Essa assertiva não inviabiliza, contudo, o entendi-

CUNHA, Manuela Carneiro da. "Política Indigenista no século XIX". In: CUNHA, Manuela Carneiro da (org.). História dos índios do Brasil. São Paulo: FAPESP/ Companhia das Letras, 1992, p. 138.

2 SAMPAIO, Patrícia Maria Melo. Espelhos partidos: etnia, legislação e desigualdade na Colônia. Manaus: 
mento do seu direcionamento político e administrativo para analisar a questão indígena sob um novo contexto acentuado progressivamente no problema da ocupação territorial, como asseverou a própria Manuela Carneiro da Cunha. Com referência a incorporação dos índios como mão de obra, Sampaio observa a especificidade da Carta de 1798 para a Amazônia. No que diz respeito à ênfase dada "à questão da disponibilidade de trabalhadores", a Carta produziu, nos anos subsequentes ao Diretório pombalino, a "individuação dos índios aldeados", por um lado; por outro, produziu a tutela "regulada pelos Termos de Educação" aos índios não aldeados. ${ }^{3}$ Nesse escopo analítico, a autora frisa que faltam estudos locais que deem conta do quadro histórico específico, no qual atuou a Carta de 1798 "[p]roduzida em uma conjuntura de mudanças políticas no ultramar e na própria colônia". ${ }^{4}$ Sampaio ressalta ainda: "uma análise da natureza e dos efeitos da Carta de 1798 pode colaborar não só na ampliação das discussões quanto à política indigenista brasileira, mas também ampliar nossa compreensão de uma região e de suas muitas especificidades". 5

Em outro estudo, Sampaio frisa que embora não houvesse na virada do século um corpo documental unificado e geral que legislasse sobre as populações indígenas, não procede a máxima historiográfica de "vácuo legal" para os primeiros anos do século XIX. ${ }^{6} \mathrm{~A}$ argumentação da autora apoia-se na observação da administração dos índios do Grão Pará e Maranhão durante aquele período, marcada por determinações régias, provisões, decretos, entre outras medidas legais específicas para aquela região. ${ }^{7}$

Para Sampaio, ao contrário de um hiato legislativo para as questões indígenas após a abolição do Diretório, o que se nota é a profusão de políticas alternativas, que atendiam diretamente as demandas regionais. Ainda salienta que, naquele momento, isto é, nas primeiras décadas do século XIX, não existia unidade administrativa para a Colônia de um modo geral. Portanto, as medidas indigenistas adotadas estavam voltadas a atender aos interesses locais.

Dentre os direcionamentos principais com relação à questão indígena sob a égide do Diretório de 1758 destacam-se dois elementos, quais sejam: mão de obra e ocupação territorial como dois temas correlacionados. O incentivo a não índios em aldeamentos e vilas de índios visava promover a mistura biológica e cultural. Promover a mistura significava uma nova forma de incorporar o índio no projeto de colonização e obter mão de obra para os serviços públicos e particulares. Nesse sentido, o trabalho indígena, que já era utilizado antes do Diretório, continua sendo um tema central tratado pela legislação. Sobre o caráter de continuidade do interesse pelo trabalho indígena após a extinção do Diretório pombalino, Fátima Lopes observa que embora a Rainha declarasse tratamento igual para todos os seus vassalos, incluindo os índios, na prática, as diferenças eram mantidas. Os índios continuavam atuando em serviços obrigatórios como o militar e como canoeiros. Permanecia em prática, portanto "o controle sobre o que identificava como a 'natural ociosidade [dos indígenas] a que os convida o clima', através do trabalho [...], que deveria ser coordenado pela junta da Fazenda e

Editora da Universidade Federal do Amazonas, 2011, p. 245.

3 SAMPAIO. Espelhos partidos, p. 246.

4 SAMPAIO. Espelhos partidos, p. 246.

5 SAMPAIO. Espelhos partidos, p. 246.

6 SAMPAIO, Patrícia Melo. "Política indigenista no Brasil imperial”. In: GRINBERG, Keila; SALLES, Ricardo (orgs.). O Brasil Imperial, volume I: 1808-1831. Rio de Janeiro: Civilização Brasileira, 2009, p. 184.

7 SAMPAIO. "Política indigenista no Brasil imperial". 
pelo Ouvidor". ${ }^{8}$, ou seja, o controle sobre o trabalho dos índios continuou a ser objeto de grande interesse da Coroa, que prescrevia, inclusive, o uso da "força" para obtê-lo. ${ }^{9}$

O decreto de 1798, que abolia o Diretório pombalino e dava outras providências, reafirmava o princípio de integração do índio ao projeto colonial com vistas a atender, principalmente a demanda de mão de obra. Nas palavras de Moreira Neto, as instruções do novo corpo legal dirigiam-se "a objetivos mais concretos, dispondo sobre a organização dos índios em corpos de trabalho". ${ }^{10} \mathrm{~A}$ nova orientação legal confirmava, mais uma vez o interesse lusitano na utilização da mão de obra indígena. Nesse escopo, Vânia Moreira confirma em seus estudos sobre o Espírito Santo de fins do Setecentos a prática do uso do trabalho compulsório dos índios. Em Nova Benavente eles eram empregados compulsoriamente em serviços públicos e em fazendas de particulares. Isso fica em evidência quando das queixas dos índios à Rainha com relação ao que eles entendiam como abuso da exploração da sua mão de obra, pois, os mesmos lembravam à d. Maria I que haviam nascido "livres de ônus de cativeiro"".

A orientação legal de organização dos índios em corpos de trabalho continuou durante o período imperial no Brasil. Segundo Claudia Fuller, na província do Pará, os corpos de trabalhadores constituíam-se pelo recrutamento de índios, mestiços e pretos para os serviços públicos e particulares. Nas palavras da autora, "se a ociosidade [dos índios] podia ser explicada [pela abundância natural do território], ela não poderia ser justificada nem mantida, cabendo o papel de coibi-la os órgãos administrativos". ${ }^{12}$ Corroboramos, portanto a ideia de que, durante o Oitocentos, o interesse pelo trabalho das populações indígenas aldeadas continuou a ser uma preocupação administrativa no Brasil.

A permanência da exploração sistemática do trabalho indígena em moldes compulsórios, nos anos imperiais, permite-nos observar os delineamentos da organização do trabalho no Brasil, ao lado de outras formas de trabalho, como o assalariado e o escravo. ${ }^{13}$ Portanto, pensar o trabalho no século XIX por uma matriz analítica, que sugere outras formas de trabalho, tais como, compulsório e não assalariado, perspectiva de análise que inclui outros sujeitos para se pensar o mundo do trabalho, torna inteligível o trabalho sistemático dos índios aldeados.

Nesses termos, estamos preocupados, neste estudo, em entender e analisar a exploração do trabalho dos índios de Ferradas em situação de territorialização. João Pacheco de Oliveira utiliza a noção de território para pensar sociedades cuja formação têm o território como o fator que regula as suas ações. Ele sugere que a incorporação de uma sociedade à situação colonial é um dos

8 LOPES, Fátima Martins. Em nome da liberdade: as vilas de índios do Rio Grande do Norte sob o Diretório Pombalino no século XVIII. Tese de Doutorado. Universidade Federal de Pernambuco. Recife, 2005, p. 395.

9 LOPES. Em nome da liberdade, p. 395.

10 MOREIRA NETO, Carlos de Araújo. Os índios e a ordem imperial. Brasília: CGDOC-FUNAI, 2005, p. 234.

11 MOREIRA, Vânia Maria Losada. "Nós índios, índios nós senhores de nossas ações... Direito de domínio dos índios e cristandade em conflito (vila de Nova Benavente, Capitania do Espírito Santo, 1795-1798)". In: MOTTA, Márcia; SERRÃO, José Vicente e MACHADO, Marina (orgs.). Em terras lusas: conflitos e fronteiras no Império Português, Vinhedo: Editora Horizonte, 2013, p. 263.

12 FULLER, Claudia Maria. "Os Corpos de Trabalhadores e a organização do trabalho livre na província do Pará (1838-1859)". Mundos do Trabalho. Florianópolis: GT Mundos do Trabalho/Associação Nacional de História, vol. 3, n. 6, 2011, p. 57.

13 Beatriz Mamigonian e Fabiane Popinigis ressaltam que, "[na] verdade, inúmeras formas de trabalho compulsório ou não remunerado coexistiam com a escravidão e se expandiam depois da abolição": MAMIGONIAN, Beatriz G.; POPINIGIS, Fabiane. "Dossiê (Outros) Trabalhadores livres no Atlântico oitocentista". Mundos do Trabalho. Florianópolis: GT Mundos do Trabalho/Associação Nacional de História, vol. 3, n. 6, 2011, p. 4. 
elementos mais significativos de sua transformação de sociedade segmentar em sociedade centralizada. ${ }^{14}$ Nesse sentido, a presença colonial "instaura uma nova relação da sociedade com o território, deflagrando transformações em múltiplos níveis de sua existência sociocultural". ${ }^{15}$ Oliveira propõe a noção de territorialização enquanto um ato político, no qual o conjunto de indivíduos ou grupos é enquadrado em determinado espaço geográfico. Esse ato político constitui objetos étnicos, através dos mecanismos políticos arbitrários e exteriores ao grupo e às relações estabelecidas "entre os diferentes grupos que integram o Estado". ${ }^{16}$ O conceito de territorialização norteia nossa análise, no sentido de permitir pensar a instauração do aldeamento de Ferradas como mecanismo de intervenção dos governos colonial e imperial sobre os camacãs, pataxós e guerens daquela parte do Sul da Bahia e, como os aldeados, nas relações estabelecidas com os diversos agentes da colonização, foram capazes de reconfigurar suas vidas no mundo territorializado.

Entendemos que garantir a existência dos aldeamentos era, para a política colonial, um meio de garantir o acesso da Coroa e dos colonos à mão de obra indígena. Esse objetivo e interesse primordial estão presentes nos aldeamentos implantados em início do XIX, e se estenderão até a política indigenista de 1845 , quando, em termos legais, o interesse pela mão de obra indígena diminui e o foco se desloca para a apropriação das terras dos índios. É nesse contexto que se instala, em 1814, o aldeamento São Pedro de Alcântara na comarca de Ilhéus, no Sul da Província da Bahia. E podemos caracterizá-lo como um "aldeamento tardio", termo cunhado por Celestino de Almeida ${ }^{17}$ Fundado no final do período colonial, o aldeamento cumpriu a função de pacificar o território a ser ocupado pela política de colonização e foi fundamental para o êxito de tal projeto. Também funcionou como reserva constante de mão de obra para os serviços públicos e particulares naquela região. Convém ressaltar, que o trabalho dos aldeados de Ferradas teve relevância marcante, na região, por todo o período de vigência do aldeamento, como sobejamente atesta a documentação primária que existe sobre ele.

\section{Expansão territorial e trabalho: a construção da lavoura dos "frutos de ouro", no Sul da Bahia oitocentista}

A Tabela 1, abaixo, do movimento de compra e venda de terras na região, que compreende a área de Cachoeira de Itabuna, nos possibilita perceber o processo de colonização e valorização da localidade. Vale ressaltar que o movimento de ocupação territorial configurou o Sul da Bahia em "região cacaueira", e isso muito se deve à atuação dos indígenas aldeados, sujeitos ativos naquele processo histórico.

14 OLIVEIRA, João Pacheco de. “Uma etnologia dos 'índios misturados”? Situação colonial, territorialização e fluxos culturais”. Mana. Rio de Janeiro: PPGAS Museu Nacional UFRJ, vol. 4, n. 1, 1998, p. 54.

15 OLIVEIRA. "Uma etnologia dos 'índios misturados'?", p. 54

16 OLIVEIRA. "Uma etnologia dos "índios misturados??", p.56.

17 ALMEIDA, Maria Regina Celestino de. Metamorfoses indígenas: Identidade e cultura nas aldeias do Rio de Janeiro. $2^{\text {a }}$ ed. Rio de Janeiro: Editora FGV, 2013, p. 102. Os aldeamentos tardios, segundo Almeida, foram aqueles espaços de catequese indígena implantados em fins do setecentos e início do oitocentos, e, embora tivessem sua fundação delimitada ainda no período colonial, mantinham características díspares dos aldeamentos jesuíticos "quanto à integração dos índios e suas relações com os colonizadores". 
Tabela $\mathrm{n}^{\circ}$ 1: Escrituras de compra e venda de terras das margens do rio Cachoeira e região de Cachoeira de Itabuna, século XIX.

\begin{tabular}{|c|c|c|}
\hline ANO & $\mathrm{N}^{\circ}$ DE ESCRITURAS & SITUAÇÃO DE CULTIVO DA TERRA \\
\hline 1814 & 01 escritura & Sorte de terras \\
\hline 1822 & 01 escritura & Sorte de terras \\
\hline 1824 & 01 escritura & Sorte de terras \\
\hline 1846 & 01 escritura & Pedaço de terras \\
\hline 1849 & 01 escritura & Pedaço de terras \\
\hline 1850 & 02 escrituras & $\begin{array}{l}\text { Pedaço de terras } \\
\text { Fazenda com plantação diversa }\end{array}$ \\
\hline 1851 & 03 escrituras & $\begin{array}{l}\text { Fazenda de cacau } \\
\text { Uma fazenda } \\
\text { Fazenda de cacau }\end{array}$ \\
\hline 1853 & 01 escritura & $\begin{array}{c}\text { Fazenda com escravos e benfeitorias (cacau e } \\
\text { café) }\end{array}$ \\
\hline 1854 & 01 escritura & Pedaço de terras \\
\hline 1855 & 01 escritura & Sorte de terras \\
\hline 1856 & 02 escrituras & $\begin{array}{l}\text { Fazenda de cacau } \\
\text { Fazenda de cacau }\end{array}$ \\
\hline 1858 & 02 escrituras & $\begin{array}{c}\text { Uma fazenda } \\
\text { Venda de pés de cacau e café }\end{array}$ \\
\hline 1859 & 01 escritura & Plantação de cacau \\
\hline 1870 & 01 escritura & Fazenda de cacau \\
\hline 1872 & 01 escritura & Uma Fazenda de cacau \\
\hline 1873 & 04 escrituras & $\begin{array}{c}\text { Uma fazenda de cacau } \\
\text { Pedaço de terras } \\
\text { Uma fazenda de cacau } \\
\text { Uma fazenda com plantação de cacau }\end{array}$ \\
\hline 1875 & 01 escritura & Uma fazenda com plantação de cacau \\
\hline 1876 & 04 escrituras & $\begin{array}{l}\text { Uma fazenda com plantação de cacau } \\
\text { Uma plantação de cacau } \\
\text { Uma plantação de cacau } \\
\text { Um pedaço de terra }\end{array}$ \\
\hline
\end{tabular}

Fonte: Tabela construída a partir dos livros de notas da vila de llhéus - Arquivo Público do Estado da Bahia. Livros: 5 e 6; 11 a 16; 20 e 21.

O demonstrativo das escrituras é irrisório do ponto de vista quantitativo. No entanto, se fizermos uma análise com base no contexto da Lei de Terras de 1850 e seus desdobramentos para aquela parte do Sul da Bahia oitocentista, podemos perceber uma configuração interessante no processo de construção da lavoura do cacau. Tendo como base o estudo de Lígia Osório acerca da Lei de Terras de 1850 e seus desdobramentos, com especial atenção à continuidade da prática do apossamento de terras mantida no Brasil mesmo após a promulgação da referida lei; e levando-se em conta, que tal prática interessava principalmente aos grandes fazendeiros; é possível afirmar, que o número de escrituras não representa, necessariamente, o nível de ocupação real da região. ${ }^{18} \mathrm{Em}$ outras palavras, a pequena 
quantidade de escrituras para Cachoeira de Itabuna não significa pouca ocupação real daquela área, pois, a prática de continuar o apossamento (ilegal, a partir de 1850) de terras pode também ter ocorrido naquela parte do Sul da Bahia, visto que, estamos falando de uma zona que se configurará, em fins do século XIX, como região cacaueira e, a esse título, acompanha a configuração dos grandes latifúndios do cacau. ${ }^{19}$

Como podemos observar na Tabela 1, a partir de 1850 não aparece mais a terminologia terras nas escrituras de compra e venda, pois, embora em pequena quantidade, o que se começa a negociar são plantações ou fazendas de cacau. Isso significa que o cultivo do cacau estava se consolidando naquela área. Para tanto, dentre outros atores sociais, os indígenas aldeados exerceram papel fundamental, não apenas como pacificadores do território, mas também como trabalhadores ativos na implantação da lavoura cacaueira, pois, cultivar o cacau, ou os "frutos de ouro", como foi emblematicamente caracterizado por sua importância econômica para a região, era uma das atribuições dos indígenas de São Pedro de Alcântara, como explicitaremos adiante.

O movimento de compra e venda de plantações e fazendas de cacau na região de Cachoeira de Itabuna testemunha o momento de ascensão da lavoura do cacau que, por sua vez, delinearia o processo de construção do Sul da Bahia como "região cacaueira". Definir Cachoeira de Itabuna como região crescentemente cacaueira é pensá-la como zona de fronteiras fluidas, ${ }^{20}$ onde se encontravam índios, escravos, autoridades governamentais, fazendeiros e pequenos colonos. Portanto, é importante reconhecer a presença indígena no processo inicial de formação das roças de cacau, ao lado da presença e da atuação escrava na incipiente lavoura cacaueira.

Em suas pesquisas e investigação sobre o Sul da Bahia oitocentista, Mary Ann Mahony desconstrói uma escrita regional, que mitificou a criação da lavoura do cacau como empreendimento, que não teria feito uso da mão de obra escrava de origem africana ou afrodescendente, supostamente apenas utilizado nos engenhos de açúcar da Ilhéus colonial. No entanto, Mahony sustenta a tese da presença escrava na lavoura do cacau, afirmando que, a presença escrava não só teria desempenhado papel fundamental para a economia regional, como também para a configuração social e política que se estabeleceria na região. ${ }^{21}$

Embora a proeminência agrícola estivesse no açúcar da Bahia colonial, em fins do século XVIII e início do século XIX, os olhares começam a voltar-se para a cultura do cacau. Mahony ressalta que, na década de 1780, as autoridades governamentais já incentivavam o plantio do cacau na parte Sul da Província. ${ }^{22}$ No entanto, o cultivo desenvolveu-se lentamente, visto que, os investidores da região "estavam

19 Os estudos mais atuais sobre a região sul da Bahia que detenham atenção sobre questões relacionadas à lavoura do cacau têm como principal referência a tese de doutoramento de MAHONY, Mary Ann. The World Cacao Made: Society, Politics and History, 1822-1919. Yale University, Estados Unidos, 1996. Bem como estudos relacionados: “'Instrumentos necessários' escravidão e posse de escravos no sul da Bahia no século XIX, 1822-1889". Afro-Ásia. Centro de Estudos Afro-Orientais. Universidade Federal da Bahia, n. 25-26, 2001, pp. 95-139.

20 Nesse processo, é bastante pertinente a definição de fronteira de MUÑOZ, Laura. "Bajo el cielo ardiente de los trópicos: Las fronteras del Caribe em el siglo XIX”. In: GUTIÉRREZ, Horacio; NAXARA, Márcia R. C. e LOPES, Maria Aparecida de S. (orgs.). Fronteiras: paisagens, personagens, identidades. Franca: UNESP, S. Paulo: Olho D'Água, 2003, p. 56: “La frontera se manifesta más como área de contacto, de encuentros y entrecruzamientos. Desde puestos de observación móviles, flotantes a veces, esas miradas perciben la imagen de una frontera viva, mutable, porosa, una zona de interacción”.

21 MAHONY. “'Instrumentos necessários”, pp. 137-138.

22 MAHONY. “'Instrumentos necessários””, pp. 105-106. 
mais interessados em madeira, açúcar e mandioca". ${ }^{23}$ Contudo, Mahony destaca o interesse dos imigrantes alemães e suíços pela lavoura cacaueira na região a partir da abertura dos portos. Realça que, na década de 1830, o Sul da Bahia já exportava anualmente 26 toneladas de cacau. ${ }^{24}$ Nas décadas posteriores, o interesse pelo fruto cresceu de forma vertiginosa naquela faixa regional. Nas palavras de Mary Mahony, "em 1888, já haviam sido plantados cacaueiros em quantidade suficiente para permitir que o Sul da Bahia exportasse 13.000 toneladas de cacau em 1900 e se tornasse um dos principais produtores mundiais". ${ }^{25} \mathrm{~A}$ autora demonstra, ainda, a proporção de pés de cacau das propriedades sul baianas em fins do século XIX. ${ }^{26}$

Para Mahony, a "discussão acerca de escravos e de escravidão em Ilhéus tem demonstrado que os escravos e a escravidão foram importantes para a cidade no século XIX e para o início da cultura do cacau". ${ }^{27}$ Na mesma direção, observamos que a política de aldeamentos de catequese na região e a atuação dos índios aldeados foram de fundamental importância no processo de formação e consolidação da lavoura em grande parte do território do Sul da Comarca de Ilhéus, tendo em vista que o aldeamento São Pedro de Alcântara ou aldeamento de Ferradas existiu na região por grande parte do século XIX. ${ }^{28}$.

A relevância e a funcionalidade dos aldeamentos nesta área são confirmados indiretamente pela exposição de Silva Campos, para quem a entrada de imigrantes nacionais na região começou e priorizou, principalmente "a parte mais cultivada do município de Ilhéus, que eram as margens do rio Cachoeira, localizando-se até à aldeia de Ferradas". 29

\section{O trabalho dos aldeados de Ferradas nos serviços públicos e particulares}

A região do Sul da Bahia foi historicamente habitada por populações indígenas, e até o início da segunda metade do século XIX os interesses do governo provincial em relação aos aldeamentos instalados na região giravam em torno da acessibilidade de colonos às terras regionais e ao trabalho dos aldeados, como fica patente na documentação analisada. Sendo assim, mesmo depois de promulgada a Lei de Terras de 1850, era notável o interesse das autoridades locais em manter em funcionamento os aldeamentos. Por isso o aldeamento de Ferradas teve um longo período de existência.

No projeto imperial destinado àquela faixa regional, o interesse mais visível que aparece na documentação é em relação ao trabalho indígena. Nisso, o sul da

23 MAHONY. “'Instrumentos necessários”, pp. 105-106.

24 MAHONY. “"Instrumentos necessários”, pp. 105-106.

25 MAHONY. “'Instrumentos necessários”,' p. 107.

26 MAHONY. “'Instrumentos necessários”, p. 108: Na década de 1880, as maiores plantações de cacau do sul da Bahia pertenciam às famílias mais ricas, que cultivavam em suas instalações em torno de 100.000 pés de cacau, além de obter engenhos de açúcar e cafezais. Já as instalações intermediárias cultivavam em torno de 5.000 a 10.000 pés de cacau e, a maior parte se constituía de pequenas propriedades que, segundo a autora, ficavam à margem da produção, com cerca de 1.000 pés de cacau.

27 MAHONY. “'Instrumentos necessários”, p. 137.

28 Não se tem notícias do aldeamento após 1861. Documento de 1868 dá notícias de sua extinção de forma muito breve: O juiz Antônio Villaça, dando esclarecimentos à presidência da província sobre o estado da estrada Ilhéus-Conquista, menciona que a estrada à margem do Rio Cachoeira até a antiga aldeia de Ferradas oferecia muitas dificuldades. Arquivo Público do Estado da Bahia (doravante APEB). Seção Arquivo Colonial e Provincial, série Justiça - juízes de Ilhéus, maço 2401, fl. 8, ano 1868.

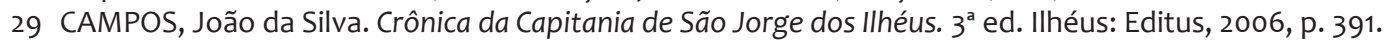


Bahia se assemelhava ao Espírito Santo, pesquisado por Vânia Moreira.30 Pois, naquela área, ao longo do século XIX, também era indisfarçável o interesse das autoridades pela mão de obra dos indígenas. Na realidade sul baiana, o assunto trabalho norteou as práticas administrativas por todo o período de vigência do aldeamento São Pedro de Alcântara.

Manuela Carneiro da Cunha destaca como caráter central na legislação indigenista, que emergiria dos debates políticos dos meados do Oitocentos, o acesso e a posse da terra. Para a autora, o interesse pelo trabalho indígena continuaria presente nas medidas políticas com relação ao governo dos índios, mas, de forma secundária e transitória.31 Porém, como ainda sugere a própria autora, "a política de terras não é, portanto, a rigor, independente de uma política de trabalho".32 Por conseguinte, diferentemente do que afirmou Cunha, a respeito da transitoriedade do trabalho indígena, observamos que no Sul da Bahia, durante todo o século XIX, o interesse pela mão de obra dos homens e mulheres em situação de aldeamento fica em evidência na documentação compulsada.

Nessa perspectiva, a partir de 1845, escreve Patrícia Sampaio: “é imperioso recuperar a permanência da questão relativa ao acesso ao trabalho indígena, que ainda era extremamente relevante, mesmo naqueles lugares em que o esforço de tomar de assalto as terras das aldeias se fez mais efetivo".33 Neste texto, empreendemos esforços no sentido de demonstrar que na região de Cachoeira de Itabuna, Sul da Bahia, na prática, a questão do trabalho indígena foi uma preocupação central, até pelo menos a década de 1870, como nos permite observar a documentação.

Também as pesquisas de Vânia Moreira insistem na importância do trabalho indígena em certas regiões do Império. Referindo à província do Espírito Santo, a autora observa "que é o sistema governativo para gerir o trabalho dos índios que entra em colapso a partir da década de 1840, não o costume de os índios prestarem serviços ao Estado e aos particulares".34 Moreira estabelece como hipótese de estudo que foi frequente a utilização da mão de obra indígena na região da vila de Nova Almeida, na primeira metade do século XIX, e que os índios foram importantes "na organização e no funcionamento do mundo do trabalho na região".35

Esta pesquisa apoia-se, dentre outras fontes, nas escrituras de compra e venda de terras e relatórios presidenciais, nas correspondências trocadas entre autoridades de Ilhéus e a Presidência da Província da Bahia. No total das correspondências relacionadas ao aldeamento, selecionamos aquelas em que aparece o tema trabalho; e, dentre essas, apenas aquelas em que fica claro o tipo de trabalho desenvolvido pelos indígenas aldeados de São Pedro de Alcântara (ver Tabela 2).

30 A autora enfrenta a produção historiográfica de invisilibização dos índios no processo de colonização brasileiro, e coloca-os no centro do debate sobre a organização social do trabalho no Espírito Santo, na primeira metade do século XIX, tendo como objeto de estudo a participação dos índios de Nova Almeida no mundo do trabalho e seus desdobramentos para a conformação social daquela região: MOREIRA, Vânia Losada. "A serviço do império e da nação: trabalho indígena e fronteiras étnicas no Espírito Santo (18221860)". Anos 90, Porto Alegre, vol. 17, n. 31. 2010, pp. 14-15.

31 CUNHA. "Política Indigenista no século XIX", p. 133.

32 CUNHA. "Política Indigenista no século XIX", p. 141.

33 SAMPAIO, Patrícia Melo. "Política indigenista no Brasil imperial”, 2009, p. 188.

34 MOREIRA. "A serviço do império e da nação", p. 28.

35 MOREIRA. "A serviço do império e da nação", p. 15. 
Tabela $^{\circ}{ }^{2}$ : Tipos de trabalho desenvolvido pelos índios aldeados, 1830-1850.

\begin{tabular}{cc} 
Décadas de 1830 e 1840 & Quantidade de ocorrências \\
Agricultura & 04 \\
Corte de madeira & 01 \\
Fabricação de canoas & 02 \\
Abertura e conservação da estrada & 02 \\
Navegação & 01 \\
Década de 1850 & Quantidade de ocorrências \\
Agricultura & 04 \\
Fabricação de canoas & 01 \\
Navegação & 01 \\
Abertura e conservação da estrada & 04 \\
Total & $\mathbf{2 0}$ \\
\hline
\end{tabular}

Fonte: Tabela construída a partir das correspondências das autoridades provinciais, seção Arquivo Colonial e Provincial, maços: 2396, 4612 e 4613. Arquivo Público do Estado da Bahia.

No conjunto das correspondências analisadas, observamos que o interesse pelo trabalho indígena continua central para o bom êxito do projeto imperial, tendo em vista a manutenção do aldeamento de Ferradas até a segunda metade do século XIX e instalação de outros aldeamentos nos mesmos moldes em outras partes da região Sul da Bahia. Ao mesmo tempo em que há um premente interesse pelo acesso a terra nesta região, já que se trata de uma área que se consolidará no final daquele século como "região cacaueira", estabelecendo-se ali os futuros latifúndios da lavoura do cacau, é patente na documentação o interesse na permanência do aldeamento e a relevância do trabalho indígena para os serviços público, particular e nas terras do próprio aldeamento.

Numa análise das correspondências oficiais das autoridades locais às autoridades provinciais, incluindo requerimentos, ofícios, dentre outras, percebemos que São Pedro de Alcântara se configurava como uma espécie de celeiro de mão de obra para os trabalhos públicos naquela área, com especial atenção para as obras destinadas a alargar, aumentar o percurso e manter em funcionamento a estrada que ligava a Vila de Ilhéus à da Vitória. Manter a estrada limpa e transitável era garantir o acesso das pessoas e, sobretudo, viabilizar o comércio entre as referidas vilas, além de assegurar, nas áreas próximas à estrada, o assento e permanência de colonos.

No que se refere à abertura da estrada Ilhéus-Vitória, em documento de 30 de junho 1843, do juiz municipal de Órfãos e delegado das Vilas de Rio de Contas, Olivença e Ilhéus, Joaquim José Pinheiro de Vasconcelos, anexo à correspondência de 1845, ao presidente da Província Francisco José de Souza Soares d'Andréa, encontra-se a seguinte informação:

[...] aprovo o expediente de que lançou mão para conseguir a abertura das estradas, que indica, como necessária a comunicação e transito dessa Villa para diversos lugares, providencia esta tanto mais vantajosa, quanto com ella se consegue o melhoramento desse Município sem dispêndio dos dinheiros públicos, cujos cofres estão em penúria $[. .].]^{36}$

A permanente necessidade de manutenção e abertura das estradas men-

36 APEB; Seção Arquivo Colonial e Provincial; Série Judiciário; Maço 2395; Ano 1845. 
cionadas nas correspondências nos conduz à própria política fundiária do século XIX, cuja efetivação requeria o alargamento dos espaços transitáveis. Para tanto, a mão de obra indígena constituía-se como seu principal suporte. Nesse sentido, é recorrente, nos documentos analisados, a menção a que a utilização do indígena como trabalhador nessas obras representava economia para os cofres públicos. Isso revela um dos aspectos proeminentes da política indigenista de 1845: o caráter "permissivo do recrutamento compulsório de índios para o trabalho público e particular". ${ }^{37}$ Em Cachoeira de Itabuna, o trabalho dos índios era empregado nas obras da estrada e visava facilitar o trânsito de pessoas e o crescimento dos municípios. Os índios eram utilizados como vetor do processo colonizador e civilizatório em curso à época, reconhecendo-se, além disso, “[...] a impossibilidade da conservação e limpeza d'ella [da estrada] por meio de outros braços que não sejam os dos aldeiados [...]".38

Em conformidade com essas assertivas estão os discursos das autoridades imperiais locais, a exemplo do requerimento de verba do capitão-mor Antônio Dias de Miranda, de 6 de dezembro de 1826:

Antonio Dias de Miranda, Capitão-Mór da Conquista do Certão da Ressaca, tendo, a exemplo de seus antepassados, empregado todos os meios a seu alcance, inda com grande dispêndio de seus bens, perigo de vida própria e de seus parentes [...] a fim de assegmentar a civilização dos gentios bravos aos arredores daquele certão, e segurança das estradas, as felizmente conseguio com grande vantagem, e proveito. Povos, por se acharem já manços os denominados = Mongoiós, e Botocudos =, vê-se em circunstancia de empregar as mesmas deligencias, e fadigas $\mathrm{Pr}$. com o denominado = Patachó [...] tendo unicamente em vista alongar a civilização daqueles povos, e fazer prosperar a cultura, o sossego dos Habitantes de seu Districto, e mais vizinhos, e a segurança das Estradas; confiando mais que tudo da Integridade, e Benignidade de V. Ex ${ }^{a}$, submisso, e Respeitoso. ${ }^{39}$

O sucesso do projeto colonizador na região de Ferradas (mas não apenas em Ferradas, tendo em vista que outros aldeamentos foram instalados na região) estava condicionado à "assimilação" dos camacãs (mongoiós), ${ }^{40}$ pataxós e dos guerens (também denominados de botocudos) ao processo de catequese nos aldeamentos, bem como à manutenção da segurança na estrada, garantindo, assim, os propósitos imperiais relativos à resolução das questões fundiárias à época. Nesse contexto, o funcionamento do aldeamento de Ferradas desempenharia papel estratégico, pois os aldeados, além de fazer o trabalho de manutenção da estrada, garantiam a segurança dos viajantes e, sobretudo, dos que ali pretendiam se estabelecer. Não é demais insistir, que, no Sul da Bahia, "quanto à ocupação de novos espaços, a preferência recaía sobre as áreas dos aldeamentos". ${ }^{41}$

Os aldeamentos instalados ao longo do século XIX, no Sul da Bahia, encontravam-se sob a administração de missionários capuchinhos italianos, que, por sua

37 MOREIRA NETO, Carlos de Araújo. Os índios e a ordem imperial, p. 258.

38 APEB, Seção Colonial e Provincial; Série Judiciário; Maço 2396; Ano 1848.

39 APEB; Seção Colonial e Provincial; Série agricultura; Maço n4613; Ano 1826.

40 Cf. PARAísO, Maria Hilda Baqueiro. O tempo da dor e do trabalho: a conquista dos territórios indígenas nos sertões do leste, Tese de Doutorado, USP: São Paulo, 1998, p. 279: Na Capitania e posterior Comarca de Ilhéus, os camacãs “são referidos por Kamacã-Mongoió, ao norte do rio Pardo; Kamacã Menian e Menian na área do Pardo, do colônia e do Mucuri, e por Caranins em Nova Viçosa e Caravelas".

41 FREITAS, Antônio Guerreiro de; PARAISO, Maria Hilda Baqueiro. Caminhos ao encontro do mundo: a capitania, os frutos de ouro e a princesa do sul- Ilhéus, 1534-1940. Ilhéus: Editus, 2001, p. 65. 
vez, mantinham o diálogo entre si. Isso indica que as autoridades imperiais estavam preocupadas em manter os aldeamentos comunicáveis, com o fim de garantir de forma mais eficiente, naquela área, a aplicabilidade dos interesses da colonização Oitocentista. Em 4 de maio de 1855, o diretor geral dos índios, Casemiro de Sena Madureira, dirigiu-se ao presidente da Província da Bahia, Álvaro Tibeiro de Moncorvo, com a seguinte informação:

Representei ao $\mathrm{Exm}^{\circ}$ antecessor de V. Ex. ${ }^{\mathrm{a}}$ que era necessário authorisar os missionários das aldêas de S. Pedro de Alcantara e os de Catulés e Barra de Catulés a abrirem comunicação fácil entre as [ditas] aldêas para prestarem-se socorros, e facilitarem o comércio com Conquista e Minas pelo Rio Pardo, e fui authorisado a fornecer $400 \$$ reis ao missionário de Ferradas em S. Pedro de Alcantara, e 300\$ ao da Barra de Catulés no Rio Pardo para os trabalhos destas estradas por officio de 27 de abril pretérito, tirados de 1:000\$ do cofre geral. ${ }^{42}$

A região em foco se encontrava copiosamente povoada por grupos resistentes ao processo de colonização desde o período colonial, principalmente os pataxós e os botocudos. Aquela faixa regional, dificilmente poderia ser considerada como domínio do governo sem o trabalho de pacificação e de disponibilização da mão de obra dos aldeados ali territorializados com esse fim. Vale notar, que o aldeamento S. Pedro de Alcântara é sempre descrito como "facilitador" do processo de ocupação territorial da região Sul da Bahia.

Além do aldeamento São Pedro de Alcântara, outros aldeamentos aparecem nas documentações do período, a saber: os da "Barra do Rio Salgado, o do Rio do Salto, o de Barra do Catolé, o do Catolé, o do Cachimbo, o do Salto do Rio Pardo, o de Santo Antônio da Cruz, o da Lagoa do Rio Pardo".43

Em correspondência de 1848, José Antônio de Sousa Passos, Juiz Municipal da Vila de Ilhéus versa sobre as vantagens de estabelecer outros aldeamentos na Vila de Ilhéus, dando como exemplo o bom desempenho do aldeamento S. Pedro de Alcântara:

[...] as razões que me fundo são as seguintes. $1^{\mathrm{a}}$ a vantagem de se conservar sempre limpa e frequentada a estrada que vai d'esta para a Villa da Victoria, que tem por base a conservação e augmento do commercio central, que hoje He nenhum pelo péssimo estado da dita estrada, e falta de abrigo em pontos certos e determinados. $2^{\text {a }}$ o pouco despendio dos Cofres Publicos, por isso que as duas referidas Aldeias podem ser estabelecidas pela maneira que foi a de S. Pedro d'Alcantara, [...] $3^{\mathrm{a}}$ a impossibilidade da conservação e limpêsa d'ella por meio de outros braços que não sejão os dos aldeiados, [...] $4^{a}$ finalmente todas as vantagens que resultão da civilisação dos Indios em geral, que a primeira vista se podem conhecer. ${ }^{44}$

Nesses documentos trocados entre autoridades locais e provinciais, o tema da conservação da estrada configura-se como uma das principais justificativas para a solicitação de recursos pelas autoridades locais à presidência da província. A correspondência expedida pelo Juiz Municipal de Órfãos da Vila de Ilhéus e outra escrita por José Antônio de Sousa Passos, e datada de 3 de agosto de 1850, destacam o bom

42 APEB; Seção Arquivo Colonial e Provincial; Série Agricultura; Maço 4612; Ano 1855.

43 ANDRADE, João Cordeiro. Missões Capuchinhas na Comarca de São Jorge dos Ilhéus (1816-1875). Monografia. Ilhéus: UESC, 2003, p. 59.

44 APEB, Seção Colonial e Provincial; Série Judiciário; Maço 2396; Ano 1848. 
andamento dos trabalhos de limpeza e melhoramento da estrada, bem como o progresso alcançado em relação à comunição terrestre entre Ilhéus e a Vila da Vitória.

Tenho presente o officio de V. Ex $x^{\mathrm{a}}$. De 19 de abril do corrente anno ora recebido, em o qual me ordena, que entregue ao missionário da Aldeia de S. Pedro d'Alcantara Fr. Vicente d'Ascoles, qualquer quantia da de $600 \$$, que eu havia recebido em 22 de Setembro de 1847 para melhoramento e limpesa da estrada que segue d'esta para a Imperial Villa da Vitoria, caso alguma exista em meu poder [...] o methodo empregado sempre e anteriormente a esta ultima limpesa da estrada, tem consistido em desobstruila, já alargando-a, [...] a qual nunca passou de huma picada d'esde que de seo principio foi aberta. ${ }^{45}$

No conjunto das correspondências imperiais percebemos diversas manifestações e esforços das autoridades para manter a estrada Ilhéus-Vitória em funcionamento e oferecer segurança aos que por ali transitavam. Conforme explicita a documentação, as condições de funcionamento e uso dessa estrada oscilaram bastante no decorrer do século XIX. De acordo com Silva Campos, a "estrada que partia da Vila para o sertão de Conquista, passando pela aldeia de Ferradas, continuava em 1855 reduzida a simples trilha".46

Dentre os motivos que culminavam nas dificuldades em manter o bom estado de conservação da estrada Ilhéus-Vitória podem-se destacar os problemas relacionados ao próprio funcionamento do Aldeamento São Pedro de Alcântara. Por ocasião dos intervalos entre as administrações do aldeamento, nos momentos de saída de um missionário diretor e chegada de outro, os indígenas aldeados se dispersavam. Isso motivou várias queixas registradas pela diretoria geral dos índios nas correspondências emitidas às autoridades provinciais da Bahia:

Considerando o deplorável estado em q' se acha a V. a de S. Pedro de Alcantara conhecida pelo nome de $=$ Ferradas do termo desta $v .{ }^{a}$ julgamos de nosso dever levando ao conhecimento de V. Excelência esta occorrencia com as considerações necessárias afim de V. Excelência providenciar conforme entender em sua alta sabedoria. Esse referido lugar das Ferradas, Exm. ${ }^{\circ}$ Snr. ${ }^{\circ}$, q' tem sempre merecido as atenções desse Exm. ${ }^{\circ}$ governo mandando para alli já este já aquele Padre missionário afim de catechisar por meio da palavra divina essa parte da espécie humana, indigna, selvagem - embrutecida alli existente denominados Camacães= trazida ao grêmio da Igreja dando-lhes o ensino da civilização, os necessários conhecimentos do justo e injusto,= se acha a pronta no mais completo abandono com a retirada á final do religioso Frei Rainero de Ovada, que teve lugar em julho do anno PP.47

A conservação da estrada exigia trabalho constante para que o mato não a destruísse. As fontes das décadas de 1840 e 1850 indicam isso. Na década de 1870, a manutenção da estrada continuava sendo uma grande questão e foram intensificados os trabalhos para sua conservação, tendo à frente os fazendeiros da região, como o estrangeiro Fernando de Steiger, que, segundo correspondência de 1868, empreendia as obras da estrada com sucesso..$^{48}$ João da Silva Campos menciona o progresso alcançado em relação aos trabalhos de melhoria da estrada Ilhéus-

45 APEB; Seção Colonial e Provincial; Série Judiciário; Maço 2396; Ano 1850.

46 CAMPOS, João da Silva. Crônica da Capitania de São Jorge dos Ilhéus, p. 375.

47 APEB; Seção Arquivo Colonial e Provincial; Série Agricultura; Maço 4612; Ano 1859.

48 APEB: Seção Arquivo colonial e provincial, série Justiça/correspondências juízes de llhéus, maço 2401, ano 1868. 
Vitória na década de 1870. Informa sobre o aumento do trânsito registrado na estrada devido ao seu bom estado de conservação, destacando ainda, as possibilidades de exploração da agricultura, que se abriam em razão do bom andamento das atividades de conservação e abertura da dita estrada:

Frei Luiz de Grava não tinha somente por ocupação administrar a Colônia. Dera-lhe igualmente o governo provincial a incumbência de melhorar a estrada de Ilhéus a Conquista e, pelo seu relatório, apresentado em 1871, vê-se que estava atacado o serviço na extensão de treze léguas, entre a Colônia e a aldeia do Catolé. Neste ano era notável o trânsito de boiadas pela estrada, vindas do sertão para a Colônia e para Ilhéus, sem embargo dos ataques dos índios (718). Prosseguindo na empresa, no ano de 1873 , das 62 léguas totais do caminho faltavam apenas seis para limpar até Ilhéus, e 12 ou 14 até Conquista, sendo os terrenos marginais excelentes para as plantações de café, cacau, cana e algodão. ${ }^{49}$

No fragmento exposto acima, Silva Campos se refere às obras realizadas na estrada em 1871. Nessa ocasião encontrava-se extinto o aldeamento São Pedro de Alcântara e já funcionava o projeto político de colonização daquela localidade por meio da colônia agrícola denominada Colônia Nacional da Cachoeira ou Colônia Nacional Cachoeira dos Ilhéus.

Depois da extinção do aldeamento São Pedro de Alcântara, os índios aldeados da região ainda atuavam nas obras da estrada. Serviam a esse trabalho os aldeados de Cachimbo, estabelecimento administrado pelo frei Luís de Grava. Notese que quando os serviços prestados pelos índios se faziam por recrutamento do Estado, em fins da década 1860, eles trabalhavam na estrada, preferencialmente, sob o comando e os interesses dos fazendeiros locais. Segundo registro feito na correspondência de 16 de agosto de 1868, enviada à presidência da província, pelo então juiz de direito Antonio Villaça:

Convencido de que a prosperidade desta Comarca depende absolutamente da estrada que d'aqui se dirige a $V^{a}$ da Victoria, e o sertão, a mais perto do litoral, em toda a Costa do Sul da Província: tive a satisfação, pela Resolução d' Assembleia Legislativa Provincial, consignado a quantia de quatro contos de reis, para limpeza da estrada [...] o prestante Estrangeiro Fernando de Steiger, que pretende fazer um estabelecimento importante no Rio Salgado, além das Ferradas, comprando terras do Governo [...]; tenho me com elle empenhado, para que se encarregue da limpeza d'aquella estrada das Ferradas a $V^{a}$ da Victoria [...], e por isso afirmar a V. Excia., que incumbindo-se elle dessa obra, de acordo com o digno Missionário d' Aldeia do Caximbo, Fr. Luis de Grava, se conseguirá um serviço de valor, [...] o missionário obtendo trabalhadores para elle de sua Aldeia. ${ }^{50}$

Nesse momento, os aldeamentos da região começaram a ser extintos, a exemplo do de Ferradas. Ao que tudo indica, os antigos aldeados passaram a viver e a trabalhar, a partir de 1870, na colônia agrícola fundada nas terras do próprio aldeamento. Nesse período, a lavoura do cacau já estava em ascensão e, por conseguinte, atraia cada vez mais o interesse de colonos nacionais e estrangeiros pelas terras da região. Desse modo, fazia-se imperioso o bom uso da estrada IlhéusVitória como ficou evidente na fala do juiz Villaça.

49 CAMPOS, João da Silva. Crônica da Capitania de São Jorge dos Ilhéus, p. 394.

50 APEB: Seção Arquivo colonial e provincial, série Justiça/correspondências juízes de Ilhéus, maço 2401, fl.o8, ano 1868. 
Interessante ressaltar, nesse momento, a relação direta estabelecida entre fazendeiros e missionários. Frei Luis de Grava era o missionário que a partir de 1870, atuaria como diretor da colônia agrícola de imigrantes e também dirigia nos idos de 1868 o aldeamento denominado de Cachimbo, próximo à Vila da Vitória. Ele disponibilizou o trabalho dos aldeados do Cachimbo para os serviços na estrada, cuja conservação estava sob os cuidados do fazendeiro Fernando de Steiger. Isso evidencia não apenas as relações entre missionários e fazendeiros, mas também que o uso da mão de obra indígena era recorrente até o final do século XIX naquela região.

No sentido de mapear os estágios de trabalho empregados na estrada, Steiger a dividiu em quatro partes. Isso nos permite visualizar, geograficamente, a região de Cachoeira de Itabuna nessa época. Assim, no dia 14 de agosto de 1868, Steiger menciona que havia "dividido esta estrada em quatro secções: $1^{\text {a }}$ da Victoria ate o Jacarandá 2 legoas, $2^{\text {a }}$ do Jacarandá ao Mutucujê 3 1/2 ditas, $3^{\text {a }}$ do Mutucujê as Ferradas (São Pedro de Alcântara) 2 ditas, das Ferradas ao Rio Salgado 3 ditas". Nesse momento, o aldeamento já se encontrava extinto, mas aparece entre parênteses, na citação a Ferradas, pela clara correlação que as pessoas ainda faziam entre Ferradas e o aldeamento dos índios.

Na sequência do documento, Fernando de Steiger menciona o lugar denominado Tabocas, que, segundo ele, ficava entre Mutucugê e Ferradas, localizando-se a uma légua acima de Mutucugê, local povoado por pequenas fazendas de cacau que prosperavam. Até os dias de hoje, Itabuna é denominada, pelos mais antigos, com o nome de Tabocas, um dos nomes que os imigrantes sergipanos atribuíram ao povoado que daria origem a atual cidade, e que nomeia um dos livros memorialistas mais importantes daquela cidade: O Jequitibá da Taboca: ensaios históricos de Itabuna, 1849-1960, de Oscar Ribeiro Gonçalves. Pelas evidências do documento citado acima, concluímos que Cachoeira de Itabuna e Tabocas era um mesmo núcleo, pois se tratava justamente da povoação próxima a Ferradas, como explicita Steiger.

Steiger segue seu relato sobre o andamento das obras e a forma como estava dividindo o trabalho na estrada, bem como as previsões para a conclusão da mesma. Dentre as informações deixadas por ele, vale citar o emprego de "1672 jornaes d'escravos" para cumprir a primeira seção da estrada, que partia da sua fazenda Vitória. Cita ainda o emprego de 65 dos seus escravos nos serviços da terceira seção da estrada. Observamos, mais uma vez, o caráter de fluidez da fronteira social que permeava aquela região e seu processo histórico de conquista e colonização, no qual atuavam religiosos, autoridades governamentais, colonos, índios aldeados e escravos. ${ }^{51}$

Dissertar sobre a relevância do trabalho indígena na estrada para garantir o êxito da política imperial na região de Cachoeira de Itabuna, bem como sobre a utilização de sua mão de obra na pacificação territorial se faz necessário e importante, pois, permite perceber como o Sul da Bahia se beneficiava da política indigenista para fins de colonização, durante o século XIX. Além disso, a manutenção

51 Caracterizamos a região sul da Bahia como região de fronteira a partir do aparato teórico que trata este conceito mais especificamente para os estudos indígenas: João Pacheco de Oliveira (1998), Maria Regina Celestino de Almeida (2001; 2013) e Vânia Losada Moreira (2010; 2011), que trataram da questão da construção da identidade do índio no mundo territorializado, processo no qual as fronteiras étnicas entre aldeados e colonizadores são mantidas na interação. Nesse bojo de reflexão teórica sobre fronteira, são fundamentais os direcionamentos teóricos de Frederik Barth (2011) - Grupos étnicos e suas fronteiras como referência fundamental para pensar a ideia de fronteira étnica entre os grupos sociais em situação de contato. 
dos aldeamentos e da estrada justificava a contínua solicitação de recursos por parte do governo local ao governo provincial. Eram esses recursos, que muitas vezes garantiam a autonomia administrativa da vila.

Procuraremos demonstrar, a partir de aqui, a atuação dos homens e mulheres em "situação de aldeamento" de Ferradas em outros postos de trabalho, tais como: trabalhos especializados (fabricação de canoas e na navegação), nas fazendas e na lavoura de cacau, ressaltando o trabalho dos aldeados na lavoura do cacau nas terras do próprio aldeamento. Tal abordagem permite enxergar a importância dos índios no processo de desenvolvimento econômico daquela região, e sua capacidade de negociar a própria mão de obra. Desse modo, as pessoas em "situação de aldeamento" não foram meras marionetes da política de colonização territorial praticada na região da Cachoeira de Itabuna.

Em correspondência não assinada pelo remetente, de 4 de agosto de 1849, enviada à Presidência da Província, informando sobre requerimento de índios botocudos, encontramos a seguinte informação:

Disem os Botocudos moradores nas margens do Rio Pardo, e suas adjacências que desejando elles supplicantes de se reunirem na sua primitiva terra situada entre o riacho Catulé, e o de S. Pedro, e alli na beira do mesmo rio formarem a sua aldea, a coadjuvarem com sustento, e braços as canoeiras da importantíssima navegação do Rio Pardo. ${ }^{52}$

Assim como a estrada, a navegação dos rios que compreendiam o Sul da Bahia era de fundamental importância para a mobilidade de pessoas e escoamento de produtos no processo de colonização daquela região. Nesse contexto, o transporte por meio de canoas era uma atividade importante, e os indígenas, habitantes daquelas paragens, sabiam perfeitamente a relevância da sua mão de obra especializada em fabricar canoas e em servir como navegadores nos rios da região.

No fragmento citado, observamos claramente a negociação proposta pelos botocudos. Em troca de se estabelecerem em terras que lhes pertenciam historicamente, ofereciam ao colonizador um serviço indispensável e que eles sabiam fazer melhor do que ninguém: construir canoas e trafegar nos rios, que eles conheciam perfeitamente bem e não raramente tornavam navegáveis. Em 5 de dezembro de 1850, a inspetoria da tesouraria provincial enviou à presidência da província o requerimento de frei Vicente Maria de Ascoli, diretor de São Pedro de Alcântara. Registrava-se "que em vista dos serviços prestados ao Ex. ${ }^{0}$ governo pelos índios da sua aldeia tanto para fazer navegável o Rio Caxoeira do ponto chamado Mutucugê até as Ferradas; abrindo treis legoas; como em marcar a estrada de comunicação entre a Villa da Victoria, e a dos Ilheos",53 seria por bem, que a presidência Ihe mandasse fornecer ferramentas de trabalho, roupas, chumbo e pólvora.

Essas observações feitas acerca da documentação disponível são imprescindíveis para percebermos como de fato se dava a relação entre aqueles dois mundos, o do colonizador, que utilizava a mão de obra indígena para tornar possível o projeto de expansão das fronteiras da província; e o do indígena em situação de aldeamento ou não, que sabia a hora de negociar com os colonizadores para fazer valer seus interesses naquele processo. Sendo assim, concordamos com Marcelo Henrique Dias, que em seus estudos sobre os aldeamentos coloniais jesuíticos, na capitania de Ilhéus, destaca a proeminência do trabalho indígena, em

52 APEB: Seção: Arquivo Colonial e Provincial, série: Juízes de Ilhéus/1840-1850, maço 2396, ano 1849.

53 APEB, Seção: Arquivo Colonial e Provincial, série: agricultura, maço 4613, ano 1850. 
contraponto a uma historiografia que prefere insistir no poder de "devastação" aimoré. Segundo as palavras do autor:

De modo geral, a historiografia que direta ou indiretamente trata da capitania de llhéus tem colocado suas populações indígenas, sobretudo aimorés e pataxós, na qualidade de principais obstáculos ao desenvolvimento de sua colonização. Já no final do primeiro século da colonização, os aimorés teriam arrasado os engenhos da vila de São Jorge e condenado a mesma a uma decadência que se estenderia até o século XIX.54

Os indígenas habitantes do Sul da Bahia, no século XIX, também aparecem como entraves ao processo "civilizador", sobretudo na escrita memorialista regional, a exemplo das obras memorialistas de Oscar Ribeiro Gonçalves e José Dantas de Andrade, para quem os índios se configuravam em obstáculos que os "pioneiros" tratariam de superar. ${ }^{55}$ Tal descrição, contudo, em nada é compatível com as informações colhidas nos arquivos, pois, o que acontecia na prática das relações entre índios e os agentes da colonização era um processo de luta de interesses, complexo o suficiente para rejeitarmos a assertiva historiográfica de que o índio era apenas um obstáculo a ser vencido. Afinal, se é verdade que os índios podiam resistir e até mesmo destruir fazendas, criações e vidas, não é menos certo que, quando aldeados, frequentemente serviam aos propósitos da colonização.

Desse modo, destacamos que na correspondência de 11 de Março de 1849, ao presidente da Província Franco Galvão Martino, o juiz municipal substituto da Vila de Ilhéus, Christiano Manoel de Sá Belsamara, menciona os prejuízos de se fazer uma nova missão nas proximidades de Ferradas. Para ele, isso significava a perda da mão de obra indígena para trabalhar nas áreas rurais do município de Ilhéus:

Tenho a saptisfação em comunicar a V. Ex a , que o Padre Frei Vicente Micionario das Ferradas, accaba de fazer um mui importante serviço a este Municipio. A estrada de comunicação para os Certões achava-se intransitável por diversos attentados praticados pelos índios Camacans, como sejão intrepes para offensa dos passageiros, attaques as fazendas cituadas na mesma estrada, mortes de animais e mesmo de indivíduos. Frei Vicente ciente destas noticias posse a marcha, acompanhado de frei Joaquim de Colorno, leigo, de um língua, e dois guias; e depois de muitos dias [...] alcansou os Camacans reprehedeu seus crimes, e redusio 62 a virem aldeiarem-se nas Ferradas. [...] encontrei aqui Frei Ludovico com outro frade, que marcharão em direção ao centro dos Certões, hindo pelo Rio Pardo, para estabellecerem uma misção, de que tomará conta o dito frade. [...] eu a julgo inteiramente opposta aos intereces d'este Municipio, pois que vai roubar lhe grande número de braços livres, que podem cultivar seus terrenos. Frei Vicente [...], pode em pouco tempo

54 DIAS, Marcelo Henrique. "A inserção econômica dos aldeamentos jesuíticos na capitania de Ilhéus". In: DIAS, Marcelo Henrique; CARRARA, Ângelo Alves (orgs.). Um lugar na história: a capitania e comarca de Ilhéus antes do cacau. Ilhéus: Editus, 2007, pp. 188-189.

55 Oscar Ribeiro Gonçalves ao tratar da chegada dos imigrantes sergipanos, Félix Severino do Amor Divino e Manoel Constantino à Ilhéus, observa o contato com os índios como os obstáculos que os imigrantes teriam que superar, ressalta que ambos, "sozinhos neste dito lugar êrmo [às margens do Rio Cachoeira], como teriam eles contemplado aquele cenário?... A mata, os caboclos e as feras eram seus únicos vizinhos": GONÇALVES, Oscar Ribeiro. O jequitibá da Taboca. Ensaios históricos de Itabuna, 1849-1960. Itabuna: Oficinas gráficas da imprensa oficial da Bahia, 1960, pp. 28-29. Na descrição apresentada por José Dantas de Andrade: "Nos raros encontros entre índios e desbravadores, a vitória ficava sempre com os segundos, obrigando a que os silvícolas, compreendendo a inutilidade de suas flechas contra as espingardas [...], fossem se aprofundando cada vez mais nas matas cedendo terreno ao avanço dos brancos". ANDRADE, José Dantas de. Documentário histórico ilustrado de Itabuna. Itabuna: Gráfica Editora Itabuna LTDA, 1968, p. 21. 
com a pretensão de V. Ex ${ }^{a}$, domesticar os Camacans, sem ser precisa outra Missão [...]. ${ }^{56}$

O juiz segue o seu relato observando que, quando chegou frei Vicente a Ferradas, com os índios, frei Ludovico os esperava para transferi-los para uma área próxima ao rio Pardo, onde instalaria outro aldeamento com os mencionados camacãs. Em tom de protesto, o juiz substituto de Ilhéus defendia que os camacãs deveriam ficar em Ferradas. Para ele, assim como frei Vicente havia conseguido convencer aqueles camacãs a aldearem-se, poderia igualmente aldear outros camacãs em Ferradas, com a ajuda financeira do Governo Provincial. O juiz lembra ao presidente Franco Galvão que frei Ludovico "nunca pôde amansar os Camacans, e desce-los a aldeiarem-se". ${ }^{57}$ Belsamara apelava para o prejuízo que representaria para Ilhéus a retirada dos índios camacãs, pois tratava-se de mão de obra livre (em termos jurídicos) que poderia cultivar as fazendas instaladas na região. O documento não deixa pistas sobre a posição dos camacãs nessa contenda. Não permite inferir se os próprios camacãs se recusavam a ficar em Ferradas - pois Belsamara lembrou que os índios resistiriam a aldearem-se no tempo em que Ludovico havia sido diretor da aldeia de Ferradas - ou se a decisão em jogo fazia-se a sua revelia.

Um dos aspectos latentes emergidos da fala de Belsamara, nesse documento, diz respeito à influência político-administrativa de frei Ludovico em toda a região, visto que o frei atuava no episódio com plena autoridade sobre os aldeados de Ferradas, embora não fosse seu administrador oficial. Ao que tudo indica sua atuação na região, por mais de três décadas, Ihe conferiu poder de articulação política, legitimando-o como um dos principais intermediadores dos interesses, tanto do governo, quanto de particulares, naquela parte do Sul da Bahia.

A decisão de Ludovico de transferir os indígenas para a região do rio Pardo incomodou as autoridades locais, a ponto de Belsamara protestar junto ao presidente da província Franco Galvão Martino com uma queixa contra o frade. Isso abre uma janela para as disputas por mão de obra indígena da época, bem como para o lugar político ocupado por frei Ludovico, que aparece como o principal administrador e distribuidor do trabalho dos homens e mulheres em "situação de aldeamento" na região.

Na região Sul da Bahia, o trabalho indígena ocupou, durante todo o século, o interesse governamental. Na segunda metade do XIX, como testemunha a documentação, procurava-se aproveitá-los no trabalho na estrada e nas fazendas, pois, como demonstramos na discussão sobre as escrituras de compra e venda realizadas em meados do século, na região, eram comercializadas plantações e fazendas de cacau, e não terras incultas (ver Tabela 1). Aquela área estava se configurando como "região cacaueira", e a utilização do trabalho dos indígenas aldeados faziase imperiosa nesse processo, tal como explicitou o juiz Belsamara, que insistiu no prejuízo para o cultivo da terra que representaria a retirada dos recém-pacificados camacãs de Ferradas.

Acerca do trabalho dos aldeados de Ferradas nos serviços dos particulares da região, assinalemos algumas observações possíveis a partir do artigo do francês H. Perret, intitulado “Aldeia do Bom Padre”, publicado no jornal O Crepúsculo:

Os indígenas que naquelles contornos residem procedem de tribus diversas; ha entre elles muitos Camacans, mormente nas imediações de

56 APEB; Seção Colonial e Provincial; Série Judiciário; Maço 2396; Ano 1849.

57 APEB; Seção Colonial e Provincial; Série Judiciário; Maço 2396; Ano 1849. 
Ermo-nobre, bella plantação de cacao do Sr. Weyll, porém estes já se achão civilisados de todo, principalmente as mulheres: os d'entre elles que são mais laboriosos podem ser utilmente empregados nas roçadas, e na extração de madeiras, e aquelles que pelas matas errão, não deixam de offerecer algum recurso aos fazendeiros, por apparecerem de vez em quando com abundante caça, que trocão por algumas bebidas espirituosas: alli a caxaça he a moeda corrente ${ }^{58}$.

Em Ermo Nobre, de propriedade do estrangeiro Pedro Weyll, os camacãs descritos como já totalmente civilizados, supomos serem os camacãs de Ferradas, tendo em vista a sequência do registro:

[...] Vimo-nos portanto na precisão de ir com a nossa canoa até o porto das Bananeiras, onde saltamos, afim de nos dirigirmos por terra à um ponto do mesmo rio, situado acima da cachoeira em que outra canoa nos esperava para nos conduzir a Ermo-nobre. Tanto neste lugar, como em Castelo-novo, recebemos o mais cordial acolhimento dos Srs. Pedro Weyll e Scola. Admiramos a plantação de cacao do primeiro, e os melhoramentos que o Engenho de assucar devia já ao segundo [...]. Os Indios Camacans que lá vimos, e o elogio que se nos fez d'aquelles que residião nas Ferradas, muito augmentaram a impaciência que tínhamos, de visitar a aldeia fundada, há mais de trinta anos, nas margens do rio Cachoeira59.

Os fragmentos citados acima confirmam a participação direta, que tiveram os aldeados de São Pedro de Alcântara na implantação e manutenção do cultivo do cacau nas fazendas da região Sul da Bahia. Atuavam não apenas em Cachoeira de Itabuna, visto que, o registro atesta a participação deles nas fazendas da região do rio Almada. Ermo Nobre e Castelo Novo foram núcleos agrícolas importantes em Ilhéus do século $\mathrm{XIX}$, que se converteram em núcleos de povoamento, posteriormente. Aqueles estrangeiros, para quem os camacãs trabalhavam, constituíram-se nas famílias mais ricas da região, responsáveis em grande medida, pelos rumos políticos e econômicos de Ilhéus e Itabuna em início do século XX. À exemplo dessas famílias, mencionamos os Lavigne, que também se utilizavam do trabalho dos aldeados de Ferradas:

[...] eis-nos de novo na Esperança, e já os nossos amigos Level e Roberto Lavigne preparão os cavallos que devem transportar-nos às Ferradas [...]. Quando os nossos amigos naquelle lugar se estabelecerão, já havia annos que o Rev. Ludovico se achava nos bosques, tinha dado principio à civilização dos Camacans, e fundado a Aldeia de S. Pedro d'Alcântara, ou Ferradas, como costumão chama-la. Aquelles Indios forão diversas vezes empregados, e com vantagem, nas obras executadas pelos novos habitantes da Esperança, que sempre achavão nelles zelo, e fidelidade, porque também da sua parte cumprirão com exatidão as promessas feitas àquelles bons indígenas; o que, seja dito entre parenthesis, nem sempre acontece, e eis a causa principal da repugnância que a mor parte dos Indios mostrão para o trabalho ${ }^{60}$.

Nota-se, portanto, o interesse dos colonos estrangeiros nas terras do Sul da Bahia, bem como o largo uso do trabalho dos indígenas de Ferradas em suas fazendas. Perret afirma que os índios de São Pedro de Alcântara haviam sido empregados muitas vezes nos trabalhos da fazenda Esperança e, "com vantagem". Ele

58 CEDOC-UESC; PERRET, H. Jornal O Crepúsculo: Salvador; edição n 13; ano 1846; p. 190.

59 CEDOC-UESC; PERRET, H. Jornal O Crepúsculo: Salvador; edição n 13; ano 1846; p. 191.

60 CEDOC-UESC; Jornal O Crepúsculo: Salvador; edição n ${ }^{13}$; ano 1846; p. 192. 
também elogia os Lavigne por cumprirem as promessas feitas aos índios e menciona o histórico de exploração indevida do trabalho deles por outros moradores. O documento não evidencia como se dava a negociação de trabalho entre os Lavigne e os aldeados de Ferradas, no entanto, fica claro que eles faziam acordos com os índios, como fica explícito também, uma realidade de exploração em moldes compulsórios do trabalho dos aldeados por parte dos fazendeiros da região.

No conjunto das correspondências analisadas, notamos que quando os índios eram pagos pelo trabalho público realizado, o eram em roupas, ferramentas agrícolas, dentre outros bens de consumo, como no caso em que o frei Vicente Maria de Ascoli, solicitou ao presidente da província, que disponibilizasse ferramentas de trabalho, roupas, pólvora e chumbo em vista dos serviços prestados pelos aldeados na estrada e na desobstrução dos rios ${ }^{61}$. Contudo, também existia a possibilidade de outras formas de negociar o trabalho dos índios. Além disso, Perret menciona que "alli a caxaça he a moeda corrente" ${ }^{62}$. Também Maria Hilda Paraíso, em seu estudo, menciona que Peter Weyl [Pedro Weyll] se utilizava do trabalho dos índios remanescentes do antigo aldeamento do Almada em troca de cachaça ${ }^{63}$. Em outras palavras, naquela realidade, certa abertura para a negociação do trabalho indígena era tão possível quanto a sua exploração de forma compulsória e não remunerada.

Em contrapartida, podemos observar que os índios não aceitavam a exploração do seu trabalho de forma passiva. Podemos notar nas palavras de Perret, que a mencionada preocupação daqueles fazendeiros em cumprir os acordos estabelecidos (embora seja bem provável que a realidade fosse outra), perdurava, porque, caso contrário eles não teriam a mão de obra dos aldeados à sua disposição, pois, como Perret mesmo lembra, muitas vezes os índios negavam-se a trabalhar para os fazendeiros.

O testemunho da documentação compulsada para esta pesquisa contradiz o que Mahony afirma sobre o trabalho indígena nas roças de cacau no Sul da Bahia, durante o século XIX. Mais preocupada em demonstrar a relevância da mão de obra escrava na lavoura do cacau, a autora afirma que os indígenas, naquele momento, assim como no período colonial, não se ocuparam muito dos trabalhos nas fazendas. ${ }^{64}$ Em nosso ponto de vista, a assertiva de Mary Mahony confirma, sem explorar as complexidades da questão, o que é recorrentemente veiculado na historiografia acerca da capitania de Ilhéus e já foi criticado por Dias: a "tão propagada incompatibilidade cultural dos índios com o trabalho sistemático". ${ }^{65}$ Ao invés disso, o autor afirma que os aldeamentos da capitania de Ilhéus "constituíram-se como parte integrante de um sistema produtivo muito original que se desenvolveu na capitania, o qual articulava à agricultura de gêneros alimentícios, sobretudo da mandioca para farinha, a extração e beneficiamento de uma gama de produtos vegetais". ${ }^{66}$ Produtos esses, importantes para o mercado interno da região.

A preocupação de Marcelo Dias é observar a participação indígena no comércio da capitania de Ilhéus, tecendo suas ponderações sobre a relevância do trabalho dos aldeamentos jesuíticos em "atividades produtivas agrícolas, extrativis-

61 APEB; Seção Arquivo Colonial e Provincial; Série agricultura; Maço 4613; Ano 1850.

62 CEDOC-UESC; PERRET, H. Jornal O Crepúsculo: Salvador, edição n 13, ano 1846, p. 190.

63 PARAISO, Maria Hilda Baqueiro. O tempo da dor e do trabalho, 1998, p. 319.

64 MAHONY. “'Instrumentos necessários”, 2001, p.98.

65 DIAS. "A inserção econômica dos aldeamentos jesuíticos na capitania de llhéus", p. 185.

66 DIAS. "A inserção econômica dos aldeamentos jesuíticos na capitania de Ilhéus", pp. 205-206. 
tas e artesanais", ${ }^{67}$ de forma a azeitar o comércio entre a capitania e o Recôncavo. Bem como ao questionar uma assertiva sobre a produção indígena apenas para subsistência no espaço do aldeamento, abre uma janela para pensarmos a atuação indígena aldeada do século XIX na dinâmica econômica regional.

Da mesma forma, as ideias de Stuart Schwartz - que analisa o uso da mão de obra indígena ao lado do trabalho escravo nos engenhos - acerca do reconhecimento do trabalho indígena nos anos coloniais na Bahia iluminam nosso interesse no trabalho indígena durante os anos imperiais. ${ }^{68}$ Schwartz salienta que "nos engenhos baianos, a escravidão, o trabalho dos índios das aldeias jesuíticas, o escambo e o assalariamento existiram simultaneamente". ${ }^{69}$ Isso significa dizer que, para Schwartz, a interação indígena com o mundo colonial permanecia, por meio de diferentes estratégias de uso da sua mão de obra, mesmo após a substituição do trabalho indígena pela mão de obra escrava africana na lavoura do açúcar.

As observações de Schwarcz e Dias demonstram as complexas relações e interações dos colonizadores com as populações indígenas e uso de sua mão de obra durante o período colonial na Bahia. Para a realidade do Sul da Bahia oitocentista, observamos na documentação compulsada e analisada uma dinâmica de uso do trabalho indígena aldeado, que os coloca no centro da configuração regional de emergência da lavoura do cacau. Ou seja, os índios de Ferradas desenvolviam atividades de agricultura no próprio aldeamento (plantavam o milho, o arroz, a mandioca, o feijão) para o sustento dos viajantes da estrada e para o seu próprio, mas também atuavam na lavoura cacaueira de forma direta e indireta.

Ainda não podemos discutir de forma aprofundada as condições de trabalho dos indígenas nas fazendas de cacau durante o século XIX, visto que a documentação em uso nos fornece pistas muito frágeis com relação a essa realidade. No entanto, vale ressaltar que a documentação atesta a importância desempenhada pelas populações indígenas do Sul da Bahia no processo de implantação e consolidação da lavoura do cacau na região. Pois foi com o trabalho direto e indireto dos índios que a lavoura de cacau foi implantada na região Sul da Bahia e foi também por meio do auxílio deles que a região transformou-se, pouco depois, em um dos maiores expoentes do cultivo e da exportação do cacau ao final do século XIX e início do século XX.

Tendo em vista sustentar nossa argumentação, evocamos a fala presidencial de João Maurício Wanderley na abertura da Assembléia Legislativa, no dia $1^{\circ}$ de março de 1853 quando ele se pronunciou sobre os aldeamentos existentes na Província da Bahia:

[...] o principal e mais importante destes aldeamentos he o de São Pedro d'Alcântara, situado à margem septentrional do rio Cachoeira, 12 legoas acima da Villa de Ilhéos [...], tem hoje por missionário e director Fr. Vicente de Ascolis, dotado de muita energia que tem chamado os índios ao trabalho com perseverança, fazendo-os plantar mais de vinte mil pés de café e vinte mil de cacao, e produzir farinha, arroz e feijão bastante para alimentação das 38 famílias da tribu Camacan, que ali há [...], o que

67 DIAS. "A inserção econômica dos aldeamentos jesuíticos na capitania de llhéus”, p. 205.

68 Schwartz observa o acesso ao trabalho indígena nos primeiros tempos da colonização com a implantação da "grande lavoura" e que perduraria de diferentes formas por grande parte do período colonial. Nesse sentido, o autor destaca três estratégias estabelecidas para o emprego da mão de obra indígena na lavoura dos engenhos de açúcar: a escravização; a tentativa de "criação de um campesinato indígena" implementada por ordens religiosas, sobretudo a dos jesuítas; e por último, o esforço de integração dos índios como trabalhadores assalariados: SCHWRTZ, Stuart B. Segredos internos: engenhos e escravos na sociedade colonial, 1550-1835. Tradução Laura Teixeira Motta. São Paulo: Companhia da Letras, 1988, p. 45.

69 SCHWRTZ. Segredos internos, p. 60. 
prova que esta aldea prospera.70 (grifo nosso)

O fragmento citado é revelador da atuação dos homens e mulheres em "situação de aldeamento" em São Pedro de Alcântara. O documento atesta que o aldeamento participava ativamente da lavoura como produtor de significativa quantidade de pés de cacau e café. Nem no período colonial, como demonstrou Dias em seu estudo sobre a capitania de Ilhéus, nem em Ferradas, o trabalho agrícola dos índios reduziu-se à produção destinada apenas ao atendimento da própria subsistência. ${ }^{11}$

Em avaliação da dimensão da plantação de cacau, na região Sul da Bahia para a década de 1880, Mahony pontua que as plantações grandes, que depois se configurariam nas fazendas dos homens mais ricos da região, compreendiam um total de 100 mil ou mais pés de cacau, e as plantações intermediárias entre 5 a 10 mil pés de cacau. ${ }^{72}$ Desse modo, levando-se em conta que em 1853 o aldeamento de Ferradas contava com uma plantação de 20 mil pés de cacau, podemos inferir que os indígenas aldeados participavam da economia comercial da região. Uma plantação de 20 mil pés de cacau, já na década de 1850 , quando a média de uma propriedade intermediária correspondia, no final do século, a metade do que existia no aldeamento, nos permite afirmar que a produção no aldeamento era bastante considerável, inserindo os índios na dinâmica da lavoura cacaueira da região.

\section{Considerações finais}

Não é nossa intenção afirmar que os camacãs e guerens de Ferradas e os homens e mulheres dos demais aldeamentos do Sul da Bahia foram a mão de obra motriz para a lavoura do cacau em ascensão; nem tampouco que tenham fundado latifúndios do cacau. Nosso objetivo foi outro: demonstrar a atuação dos indígenas de Ferradas como agente de um processo histórico complexo e multifacetado, que lhes impôs o ônus da conquista e muitas perdas e transformações sociais e culturais, mas, certamente, deu-lhes também possibilidades de elaborar novas estratégias de vida e de reconfigurar suas identidades dentro de um novo mundo.

Os aldeados de Ferradas atuaram na conformação da região Sul da Bahia enquanto "região cacaueira", ao lado de outros atores sociais, e a nova configuração econômica regional refletia os interesses políticos e sociais para a região. Considerar a proeminência do trabalho indígena nos serviços da estrada Ilhéus-Vitória (Vitória da Conquista), bem como na construção da lavoura do cacau, é imperioso para perceber o funcionamento das estratégias políticas e administrativas indigenistas com vistas a garantir, através do processo de territorialização dos índios em aldeamentos, a exploração do trabalho das populações indígenas para o êxito do projeto imperial naquela parte do Sul da Bahia durante o século XIX. No entanto, é importante reconhecer a participação deles no processo de construção da lavoura do cacau, como mão de obra e como protagonistas de sua experiência histórica.

Recebido em 03/08/2014 Aprovado em 17/03/2015

\footnotetext{
70 Relatórios Provinciais Presidenciais (1830-1930): Fala que recitou o presidente da Província da Bahia, João Maurício Wanderley, $1^{\circ}$ de março de 1853, p.35. Disponível em: http://www.crl.edu/brazil/provincial/bahia. 71 DIAS. "A inserção econômica dos aldeamentos jesuíticos na capitania de llhéus", p. 185.

72 MAHONY, Mary Ann. “'Instrumentos necessários”, 2001, p. 108.
} 